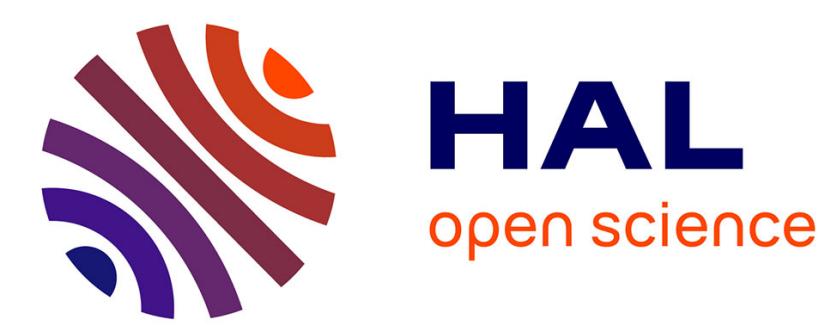

\title{
SINGLE PULSE AND CW MULTIPLY DOPED Ho: YAG AND Ho: YLF LASER
}

Y. Kalisky, Jérémy Kagan, D. Sagie, H. Lotem

\section{To cite this version:}

Y. Kalisky, Jérémy Kagan, D. Sagie, H. Lotem. SINGLE PULSE AND CW MULTIPLY DOPED Ho: YAG AND Ho: YLF LASER. Journal de Physique Colloques, 1987, 48 (C7), pp.C7-363-C7-365. 10.1051/jphyscol:1987787 . jpa-00227091

\section{HAL Id: jpa-00227091 https://hal.science/jpa-00227091}

Submitted on 1 Jan 1987

HAL is a multi-disciplinary open access archive for the deposit and dissemination of scientific research documents, whether they are published or not. The documents may come from teaching and research institutions in France or abroad, or from public or private research centers.
L'archive ouverte pluridisciplinaire HAL, est destinée au dépôt et à la diffusion de documents scientifiques de niveau recherche, publiés ou non, émanant des établissements d'enseignement et de recherche français ou étrangers, des laboratoires publics ou privés. 


\title{
SINGLE PULSE AND CW MULTIPLY DOPED HO:YAG AND HO:YLF LASER
}

\author{
Y. KALISKY, J. KAGAN, D. SAGIE and H. LOTEM
}

Laser Department, Nuclear Research Centre-Negev, P.0. Box 9001 , IL-84190 Beer Sheva, Israel

\section{Abetract}

A comparison of the laser performance of the $=1\rangle *=I_{0}$ transition at 2.1 micron in multiply doped Ho:YLF and Ho:YAG both in CW and pulaed operating modes is reported. CW operation was carried out at liquid nitrogen temperature, while the pulsed laser was operated in the temperature range from B6K to 220K. In both $Y A B$ and $Y L F$, the laser threshold shows a fast rise with temperature. The total laser power at high pumping levels gradually decreases with temperature in YAG. In YLF, however, the lager output is peaked around $150 \mathrm{~K}$. The 1 aser performance as function of temperature, pumping energy and coupling mirror will be presented.

\section{Introduction}

The importance of laser mmission of various rare earth ions doped in crystal matrix in the spectral range of 1.3-2.5pm is well established. In particular, the 2.1un laser line of $\mathrm{Ho}^{3+}$ appears to be an attractive potential candidate as a source for rangefinders, target illuminators, parametric oscillators and for medical applications"i". Hos. exhibits a relatively long lifetime of the emitting level $=I>$, which results in a high energy storage capability and efficient Q-Switched operation 2$\rangle$. As a result, several studies of CW and pulsed Holmium 1 aser operation and spectroseopic studies of some Ho doped crystals have been conducted and reported 's-4), with emphasis on YLF and YAG doped $H^{3}+$. Although YLF exhibits a negative change of its 3efraction index versug temperature (thus implying lower thermal lensting in YLF than in YAQ), it also shows a lower thermal conductivity than $Y A Q$, which 1 imits the operation to relatively low average power applications. The thermal load on the crystal can be minimized by employing a pulaed pumping source. Since YAB is much easier to handle than YLF, it is useful to compare the two hosts and

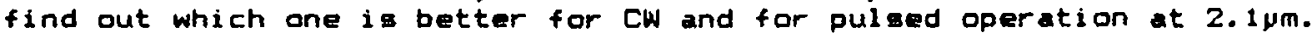
It is also important to investigate solarization effects, which are conmidered as a limitation factor in the operation of rare earths doped YAB laser materials $\approx$.

\section{Experimental}

The experimental set-up has been described recently (s). Briefly, the laser pumping head was a watar cooled elliptical reflector coated by gold for CW operation or silver for pulsed operation. The pumping source for the CW Holmium laser is a tungsten-halogen lamp with input electrical power levels (at $50 \mathrm{~Hz}$ ) of up to $1500 \mathrm{~W}$. A xenon flashtube (3mm bore diameter, 450 torr), pumped in the range of 303 - 2903 was employed in the pulsed version. The evacuated laser head is sealed by two antireflection comed IR-quartz windows, thus allowing laser operation with external mirrors. The laser rear reflector is a $2 m$ concave mirror caated for maximum reflectivity at zpm. The front 
mirrors used were in the reflectivity range of between $50 \%$ to $95 \%$. Al 1 the rods (supplied by Litton Airtron, by Sanders Assoca ates and by the crystal growth unit at NRCN) were of $75 \mathrm{~mm}$ in length, $5 \mathrm{~mm}$ in diameter, with plane parallel AR coated ends. Both YLF and YAG crystals were highly doped with $\mathrm{Er}^{+5}$ and $\mathrm{Tm}^{+3}$ and with a low concentration of $\mathrm{Ho}^{-3}$. The strong and broad absorption bands of Ersand the consequent energy transfer through $\mathrm{Tm}^{3+}$ ions to $\mathrm{Ho}^{3 \rightarrow}$ ions, leads to an increase of the cavity transfer efticiency and thus contributes to the overall laser efficiency (z). The laser rods were tested for lasing perfomance in the same cavity. With each laser rod, the laser output emission was measured as a function of the 1 amp input power, and from that measurement the laser slope efficiency was obtained.

\section{Resultts and_Discussgion}

We first deal with the CW laser working mode. Working with Ho:YLF, more than 10 rods from three different boules were dynamically cheched in the laser cavity. Two of the boules were of identical nominal concentration (namely, $0.1 \%$ at. of $\mathrm{Ho}^{3+}$ ), while the third boule was grown with $0.2 \%$ at. of $\mathrm{HO}^{ \pm .}$. The laser power versus 1 amp power is quite 1 inear up to the $1.5 \mathrm{KW}$ input power used. The slope efficiencies measured for Ho: YLF ranged from 2.6\% to 4.7\% lusing an output coupler of $R=80 \%$ in all (ases). Laser power above bOW (with a slope efficiency of $4.75 \%$ ) was achieved in some of the rods (see Fig. 1 ) at both two holmium daping levelg in YLF. It is worth while to note that no clear difference in slope efficiency or performance between the two different doping levels was observed. The loss value in the laser rod was obtained from a measurement of the laser output power as a function of lamp electrical power, for different output couplers. (U) A representing value of the 1055 is $0.7 \% / \mathrm{cm}$ for the Ho: YLF rods \langle\rangle$\rangle$.

Working with Ho: YAG, five rods from the same boule were systematically compared in the laser system as above. Fig. 2 presents the results of the laser output power versus lamp power for rod \#3 (with a nominal concentration of $0.5 \%$ at of $\mathrm{Ho}^{\mathrm{s}} \cdot \mathrm{\}}$. As is clearly seen from the figure the laser threshold in HO:YAG is sensitive to the magnitude of the output coupling. The average slope efficiency obtained for Ho: YAG with the $80 \%$ mirror is $3.4 \pm 0.2 \%$ with $0.4 \%$ standard deviation, while the round trip loss in the rods was found to be around $1 \% / \mathrm{cm}^{\text {c }}>$,

Single pulse Holmium YLF and YAG laser was operated at various temperatures ( $86 K-22 O K$ ) and at different input electrical energies. In both HO:YLF and Ho: YAG, the laser threshold increases sharply with the increase of the temperature. As expected, the laser threshold and slope efficiency depend on the value of the output coupler. At $R=50 \%$ (the lowest available mirror), the best laser performance, with up to 2. $4 \mathrm{~J} /$ pulse in YLF was obtained. 


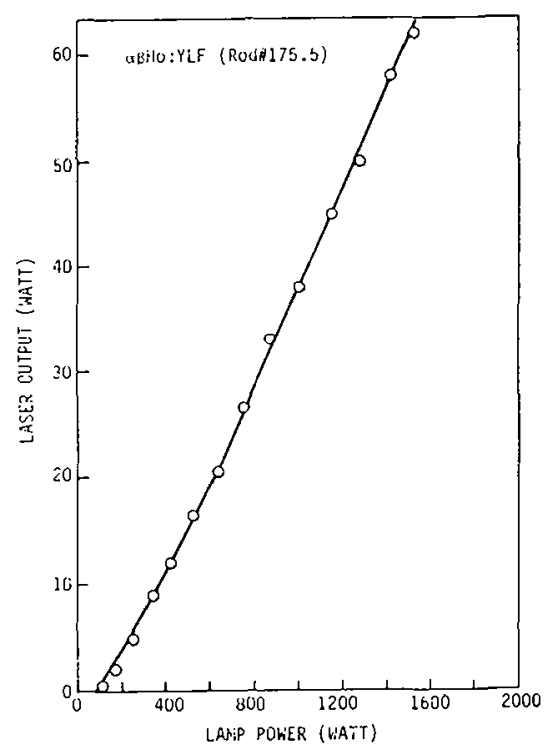

Figure 1.

CW laser power versus lamp electrical power for $\alpha \beta$ Ho: YLF

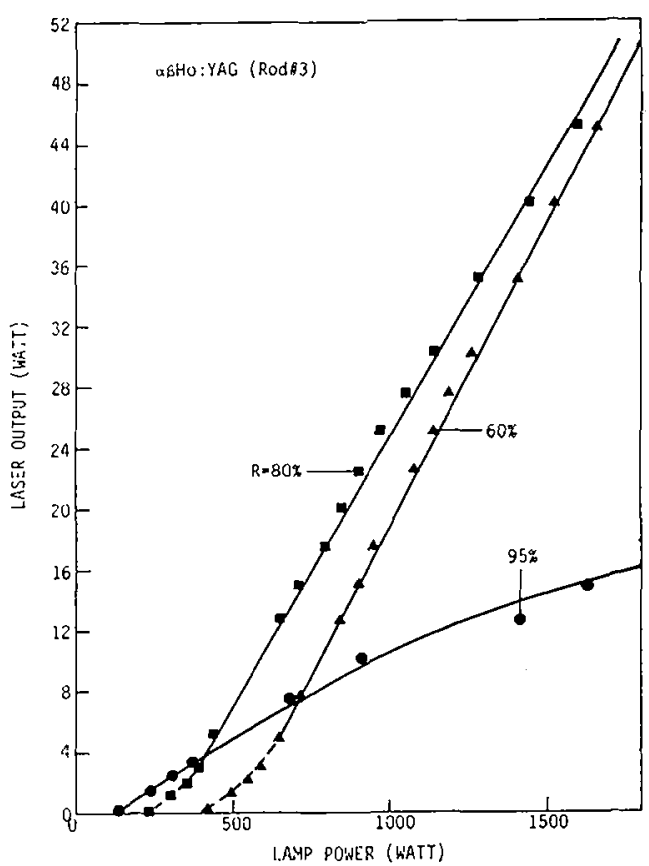

Figure 2.

CW laser power versus 1 amp electrical power for $\alpha \beta$ Ho: YAG with three output couplars

In YAG, the laser output was decreased with temperature. In YLF, at high level of xenon lamp pumping, the laser output energy was increased with the increase of temperature from liquid nitrogen temperature up to about 150K, and then gradually decreased. This unexpected phenomenon which was observed only at high lamp extitatjon energy will be explained and modelled shortly.

\section{References}

1. See for example: D. Aravot, E. Lachman, S. Biler, I.Kaplan, D. Sagie, J. Kagan and $Y$. Kalisky. The Holmium Lager in Tissue Welding, 7th Eongress of the International Society for Laser Surgery and Medicine, Munich, 22-26 June (1997).

2. E.P. Chicklis, C.S. Naiman, R.C. Folweiler, D.R. Gabbe, H.P. Jenssen and A. Linz, Appl. Phys. Lett. 19, $119(1971)$.

3. R. Beck, K. Gurs, J. Appl. Phys. 46, 5225 (1975).

4. N. P. Barnes, and D.J.Bettemy, IEEE J. Quantum Electron. QE-17, 1303 (1981).

5. L.F. Johnson, K.A. Ingersoll, J. Appl. Phys. 44544 (1973).

6. W. Koechner, Solid State Lasar Engineering, Chapter 3 , Springer-Verlag New York, Heidelberg, Berlin, (1976).

7. Y. Kalisky, J. Kagan, H. Lotem and D. Sagie, submitted to Dptics Communications (1987). 